\title{
Why People Intent to Invest Using Islamic Fintech: An analysis of Perceived Benefit, Risk, and Maqoshid Sharia
}

\author{
Dona Ramadhan ${ }^{1}$, Dedi Wibowo ${ }^{2}$ \\ \{dona.ramadhan@ui.ac.id'1, bowo15101971@yahoo.com²\}
}

University of Indonesia ${ }^{1}$, Magister Manajemen FEB Universitas Indonesia, Fakultas Ekonomi Universitas Dirgantara Marsekal Suryadarma, Faculty Technology Management \& Technopreneur University Teknikal Malaysia Melaka²

\begin{abstract}
Financial Technology (Fintech) has been interesting topic for recent years, which is driven by sophisticated digital technology in what so-called Industrial Revolution 4.0 era. Indifferent with non-digital financial institution (NDFI), Fintech could be categorized into conventional and Islamic (sharia compliance). Islamic Fintech has become the evidence that Islam and technology could be integrated and stand togeher. This paper aims at measuring the effect of perceived benefit, perceived risk, and perceived Maqoshid sharia on the intention to invest in Islamic Fintech, on a basis of 542 samples from NDFI workers. A conceptual model was adopted from Theory of Planned Behavior and tested using Structural Equation Modeling Maximum Likelihood Estimation. The empirical result shows that there is significant positive impact of perceived benefit 2.67 and perceived Maqoshid sharia 8.53, and a significant negative impact of perceived risk -1.68 toward the investment intention. We summarize that the perceived risk is strong predictor of intention. On the other hand, Islamic Fintech shall pay more attention on perceived Maqoshid sharia especially on justice and social responsibility.
\end{abstract}

Keywords: Islamic Fintech, Perceived Benefit, Perceived Risk, Perceived Maqoshid.

\section{Introduction}

Financial Technology (Fintech) has been interesting topic for recent years. Resemble with its traditional peer, Fintech offers vary financial products such as loan, investment, insurance, donation, etc, [1] and also be categorized into conventional and Islamic (sharia compliance) based on its operational processes. The emergence of Fintech, driven by sophisticated development of digital technology [2], that enabled every person to access financial services every time and everywhere. Thus, Fintech would benefit the society through increasing financial inclusion [3-5]. Moreover, Fintech also has advantages for its customers, like convenience, simple process, as well as cost savings, compared to traditional institution [6,7].

However, along with its advantages, financial transaction using Fintech escalate the risk, since all process executed automatically by system. According to previous studies, there are several types of risks related to online transactions [5-7]. Yet, we found three types which relevant with our study, those are financial, privacy, and technology.

Thirdly, as Islamic institution, Fintech should pay attention on how achieving the objectives of sharia (maqoshid sharia) which indicated by Maqoshid Sharia Index (MSI) and Islamic religious values [8-11]. Previous studies found that religiosity influences positively and significantly on purchase intention. Another study conducted by [12] concluded that religiosity is one of the factors that influence buying decisions. Religiosity itself is defined as "a person's level of obedience to religious values, beliefs, and daily activities" [13] is one We noticed three indicators suitable with our study, namely hifzhu dien, maslahah, and hifzhu maal.

We start our research from the slow rate of growth of Islamic banking in Indonesia, which remains at $5.7 \%$ in 2018. As the largest Moslem country in the world, the number should be better. Secondly, we discussed the theoretical background and previous research on perceived benefit, risk, as well as operational definition of maqoshid sharia. We applied Azjen's Theory of Planned Behavior (TPB) in developing model of analysis. Thirdly, we conduct the survey of Non-Digital Financial Institution (NDFI) workers using questionnaire as data collection tools. Given there are similarities between Fintech and NDFI, it is interesting to study the Fintech from workers point of 
view and how their intention on investing using Fintech. Moreover, NDFI workers shall have an in-depth understanding about operational process of financial institution. Once the data collected sufficiently, we analyze the result using Structural Equation Modeling (SEM). Finally, we summarize this study with general discussion of the findings, implications, limitations of the research, and direction for future study. We hope this research would contribute an alternative in increasing Islamic banking market share in Indonesia, and even farther, this study will slightly spread the light of sharia.

\section{Literature Review}

\subsection{Islamic Fintech}

Financial Service Authority (OJK) define Fintech as the use of technology in the financial system that can produce new products, services, technology and/or business models, and can have an impact on monetary stability, financial system stability, and/or efficiency, smoothness, security, and reliability of the payment system [14]. There is no consensus in the definition of Fintech, so the term Fintech itself could be interpreted with various meanings, both from a theoretical and practical point of view. Arner, Barberis, \& Buckley (2015) explains that Fintech terminology refers to the use of technology in providing financial solutions, and this novel technology has transformed from its 1 st version in 1866 [15].

As same as a financial institution, we could classify Fintech based on operating type as conventional and Islamic Fintech. Islamic Fintech is a financial institution to run its daily operation in accordance with Islamic rules and used a specific type of contract. The prominent distinction between these two institutions is on how they generate income. The conventional applies to interest, while the Islamic one uses margin as income.

Fintech and its traditional counterpart's business model have an industrial resemblance. We note several businesses operated by Fintech, such as payment, wealth management, crowdfunding, peer-to-peer lending, insurance, fund transfer, and saving [1,16]. We identify the most significant three business models of Fintech for Indonesia market in particular namely payment, crowdfunding, and peer-to-peer lending.

\subsection{Theory of Planned Behavior}

Theory of Planned Behavior (TPB) describes the consumer behavior toward product or services. First proposed by Ajzen in 1985, TPB is the extension of Theory of Reasoned Action (TRA) that tried to understand and predict human behavior. The main concept proposed by both models is that human behavior determined by three motivating factors, normative belief, subjective norm, and control belief. "Intention" become antecedent between three motivating factors and behavior, as shown in Figureure 1 [17,18].

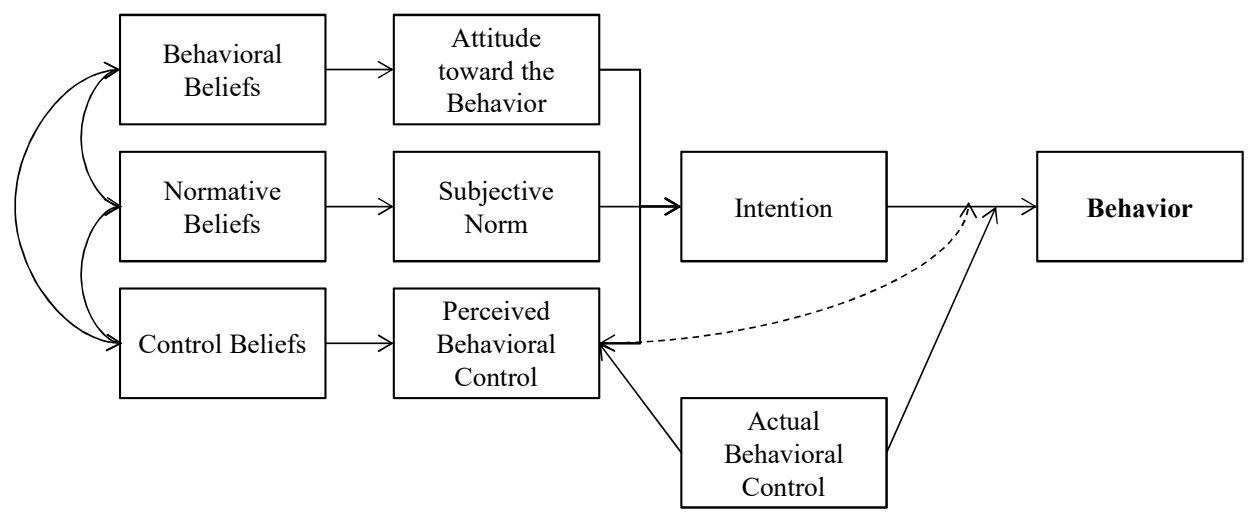

Figure 1. Theory of Planned Behavior 
This theory based on the premise that individuals make logical, reasoned decisions to engage in specific behaviors by evaluating the information available to them. The performance of a behavior is determined by the individual's intention to engage in it and the perception that the behavior is within his/her control.

\subsection{Customer Perceived Value}

Customer perceived value is consumer evaluation of the difference between all benefits (benefits) and relative costs in one offer with another offer. Customers sometimes do not assess the benefits and costs accurately and objectively, but rather the perception of the values they will obtain [19]. Perception is defined as a way of understanding or interpreting experiences that have been gained [20] Perception of values is multidimensional, as a construct of the perception of price, quality, quantity, benefits, and sacrifice [21].

Purchase decision to buy a product or use a service begins with need or problem that customer must be addressed. [19] mention five stages of customers when buying products or services, namely recognizing problems, seeking information, evaluating alternative solutions, having intentions, and deciding to buy. This theory notices that intention become predecessor of purchase decision, because there might be some factors caused customers did not buy products or services eventually [19].

The concept of perceived risk was first introduced by R.A Bauer (1960) in his study about consumer behavior [22]. Perceived risk is a combination of probability effects, namely uncertainty, when deciding to buy and the outcomes or consequences that occur [22]. Perceived risk is associated with a variety of products and services and tends to increase in the conditions when existing information is insufficient; the products or services is relatively new; the products or services offered at high prices; involves complicated technology, brands differ in quality, causing consumers to make inferior choices, consumers have low confidence and experience of the products and services [23].

\subsection{Perceived Benefit}

The concept of perceived risk was first introduced by R.A Bauer (1960) in his study about consumer behavior. Perceived risk is a combination of probability effects, namely uncertainty, when deciding to buy and the outcomes or consequences that occur [22]. Perceived risk is associated with a variety of products and services and tends to increase in the conditions when existing information is insufficient; the products or services is relatively new; the products or services offered at high prices; involves complicated technology, brands differ in quality, causing consumers to make inferior choices, consumers have low confidence and experience of the products and services [23].

\subsection{Perceived Risk}

The concept of perceived risk was first introduced by R.A Bauer (1960) in his study about consumer behavior. Perceived risk is a combination of probability effects, namely uncertainty, when deciding to buy and the outcomes or consequences that occur [22]. Perceived risk is associated with a variety of products and services and tends to increase in the conditions when existing information is insufficient; the products or services is relatively new; the products or services offered at high prices; involves complicated technology, brands differ in quality, causing consumers to make inferior choices, consumers have low confidence and experience of the products and services [23].

Forsythe et al, [6] highlighted indicators of perceived risk, namely product risk, financial risk, and time risk, as a type of risk that is often associated with internet transactions. Product risk occurs when the product is not as expected (Horton, 1976 in [6]). Financial risk is defined as the potential loss from money paid (Derbaix, 1983 in [6]). Since fintech is a financial institution, it contains risks as same as traditional financial institutions. Credit risk can occur due to various conditions that cause users not to be able to return investor funds [24]. 
Based on previous research and studies, it was concluded that perceived risk shows a negative relationship to purchase intention (in this context using sharia fintech services). Regarding perceived risk variables, the authors propose the research hypothesis as follows:

Hypothesis 2: Perceived Risk has negative impact on investment intention using Islamic fintech services.

\subsection{Perceived Maqoshid Sharia}

Perceived maqashid sharia is defined as public perception of how Islamic Fintech implements sharia objectives (maqoshid sharia). There are three maqashid sharia indicators, education, justice, and welfare [11]. As the implementation of those indicators, they proposed the measurement of Maqashid sharia for financial institutions namely Maqashid Syariah Index (MSI), as follow:

Table 1. Maqashid Syariah Index

\begin{tabular}{ll}
\hline Concept (Objectives) & Dimension \\
\hline 1. Educating Individual & D1.Advancement of Knowledge \\
& D2. Instilling new skills and improvement \\
& D3. Creating Awareness of Islamic banking \\
2.Establishing Justice & D4. Fair Returns \\
& D5.Cheap product and Services \\
& D6. Elimination of negative elements that breed injustices \\
& D7. Profitability \\
& D8. Redistribution of income \& wealth \\
& D9. Investment in the vital real sector \\
\hline & Source: Mohamed et al., 2008
\end{tabular}

In this study, we combine MSI (profitability) and religious values based on maqashid sharia, to examine how respondents perceive the implementation of maqashid sharia at the institutional level of Islamic Fintech companies.

A study by Nora, Liza \& Minarti [25] concluded that religiosity influenced positively and significantly on purchase intention. Another study conducted by [12] concluded that religiosity is one of the factors that influence buying decisions. Religiosity itself is defined as "a person's level of obedience to religious values, beliefs, and daily activities" [13]. Thus, we can conclude that religiosity is a behavior in accordance with religious values and has a good influence on behavioral intention, in this case, the intention to invest using Islamic fintech services.

Imam Al-Ghazali (d. $1111 \mathrm{CE}$ ) has formulated the conception of maqashid sharia in order of necessity such as dharuriyat, haajiyat, and tahsiniyat. The dharuriyat then divided into five categories after coined the term 'preservation (hifzu)' before the words, there are (1) faith, (2) soul, (3) mind, (4) offspring, and (5) wealth [8]. In term of Islamic financial transaction, we then propose faith and wealth as the dimensions of maqoshid sharia. Faith reflected on the individual belief of moslem about their wealth or treasure, namely not dealing with usury and giving alms [26]. Wealth is reflected on how the financial transaction generate profit [11]. Finally, the general rule of maqoshid sharia is about gaining benefits (maslaha) and preventing harms [27]). Faith, wealth, and maslaha then become the indicators of this research.

Based on previous study, that the level of implementation of religious values (which means the application of maqashid sharia) affects consumer decisions to buy products or use services, we propose the research hypothesis as follows:

Hypothesis 3: Perceived maqashid sharia has positive impact on investment intention using Islamic fintech services. 


\section{Methodology}

\subsection{Instrument Development}

To examine about the perception and intention of NDFI workers, a survey questionnaire was developed based on the review of literatures. There are fifteen indicators used to measure four constructs using on this questionnaire, those are perceived benefit four items, perceived risk four items, perceived maqoshid sharia four items, and intention four items. Details of the indicators are shown in table 2:

Table 2. Indicators of questionnaire

\begin{tabular}{lllc}
\hline No & Code & Indicators & Reference \\
\hline 1 & BEN1 & Easily to access using smartphone and/or website & {$[6]$} \\
2 & BEN2 & Transaction could be done anytime and anywhere & {$[6]$} \\
3 & BEN3 & Sufficient Information about investment transaction & {$[28]$} \\
4 & BEN4 & Saving money & {$[28]$} \\
5 & RIS1 & No collateral & {$[24]$} \\
6 & RIS2 & Investee do not have adequate skills & {$[24]$} \\
7 & RIS3 & Automatic 5Cs analysis & {$[29]$} \\
8 & RIS4 & Private date leak or breach & {$[7]$} \\
9 & SYR1 & Usury is the main difference between Islamic and conventional finance & {$[26]$} \\
10 & SYR2 & Fair profit sharing between investor and investee & {$[11]$} \\
11 & SYR3 & Islamic Fintech will frequently conduct CSR & {$[30]$} \\
12 & SYR4 & More profitable than time deposit product & {$[11]$} \\
13 & INT1 & I intent to invest using Islamic Fintech & {$[31]$} \\
14 & INT2 & I will invest using Islamic Fintech & {$[31]$} \\
15 & INT3 & I will recommend Islamic Fintech to my colleagues & {$[32]$} \\
\hline
\end{tabular}

\subsection{Research Model}

This research examines the impact of perceived benefit, perceived risk, and perceived maqoshid sharia toward investment intention using Islamic Fintech. The structural model could be seen in following Figureure:



Figure 2. Research model 


\section{Result and Discusion}

\subsection{Respondent profile}

The self-administered questionnaire was designed to examine the perception of NDFI workers toward Islamic Fintech using Likert scale 1-5. We have collected 592 samples both online and offline. Unfortunately, 50 of it was not in accordance with research design, leaving 542 valid questionnaire samples. The profile of respondents is shown in following table:

Table 3. Respondent profile

\begin{tabular}{lcr}
\hline Sex & Sample & $\mathbf{\%}$ \\
\hline Male & 340 & $62.73 \%$ \\
Female & 202 & $37.27 \%$ \\
\hline Age & Sample & $\mathbf{\%}$ \\
\hline 0 s.d 24 years old & 62 & $11.44 \%$ \\
25 s.d 29 years old & 132 & $24.35 \%$ \\
30 s.d 34 years old & 134 & $24.72 \%$ \\
35 s.d 39 years old & 139 & $25.65 \%$ \\
40 s.d 49 years old & 65 & $11.99 \%$ \\
50 s.d 60 years old & 8 & $1.48 \%$ \\
Di atas 60 years old & 2 & $0.37 \%$ \\
\hline Highest Degree & Sample & $\mathbf{\%}$ \\
\hline Master/Doktoral (S2/S3) & 14 & $2.58 \%$ \\
Bachelor/Diploma & 493 & $90.96 \%$ \\
(S1/D3/D2/D1) & 35 & $6.46 \%$ \\
High School & Sample & $\mathbf{\%}$ \\
\hline Household Expenditure & 20 & $3.69 \%$ \\
\hline Rp 0 - Rp 1 million & 90 & $16.61 \%$ \\
Rp 1 million s.d Rp 2 million & 149 & $27.49 \%$ \\
Rp 2 million s.d Rp 3 million & 161 & $29.70 \%$ \\
Rp 3 million s.d Rp 5 million & 72 & $13.28 \%$ \\
Rp 5 million s.d Rp 7,5 million & 22 & $4.06 \%$ \\
Rp 7,5 million s.d Rp 10 million & 28 & $5.17 \%$ \\
More than Rp 10 million & &
\end{tabular}

From the table above we could summarize that majority of respondent is male $(62.73 \%)$, age between 25-39 (74.72\%), education level at bachelor degree (90.96\%), and average household expenditure between IDR 3-5 mio (29.70\%). We than categorize the age of respondent based on their generation Baby Boomers, X, Y, and Z [33], and we find that generation Y is the majority of respondents (detail as follow):

Table 4. Generation of respondent

\begin{tabular}{lcr}
\hline Generation & Number & $\mathbf{\%}$ \\
\hline Generation Z $(0-24$ years old $)$ & 62 & $11.44 \%$ \\
Generation Y $(25-39$ years old $)$ & 405 & $74.72 \%$ \\
Generation X $(40$ - 60 years old $)$ & 73 & $13.47 \%$ \\
Baby Boomers $($ Over 60 years old $)$ & 2 & $0.37 \%$ \\
\hline
\end{tabular}

\subsection{Validity and Reliability}

Validity and reliability test was conducted to ensure the indicators of variable are valid and reliable. We conduct Kayser Mayer Olkin (KMO) Measure of Sampling Adequacy (MSA) for content validity testing and Cronbach's Alpha coefficient for internal consistency test. The threshold of goodness for MSA is 0.5 while Cronbach's Alpha 0.7 [34]. Score of MSA and Cronbach's Alpha coefficient could be seen on table 5. All of indicators has MSA score $>0.5$ and Cronbach's Alpha $>0.7$, thus we determine that the data are valid and reliable to be analyzed. 
Table 5. Validity and reliability test

\begin{tabular}{lccc}
\hline Variable & Indicator & MSA & $\begin{array}{c}\text { Cronbach's } \\
\text { Alpha }\end{array}$ \\
\hline Perceived Benefit & BEN1 & 0.782 & 0.813 \\
& BEN2 & 0.777 & \\
& BEN3 & 0.896 & \\
Perceived Risk & BEN4 & 0.922 & \\
& RIS1 & 0.899 & 0.757 \\
& RIS2 & 0.793 & \\
Perceived Maqoshid & RIS3 & 0.789 & \\
Sharia & RIS4 & 0.842 & \\
& SYR1 & 0.923 & 0.794 \\
Intention & SYR2 & 0.885 & \\
& SYR3 & 0.89 & \\
& SYR4 & 0.866 & \\
& INT1 & 0.839 & 0.756 \\
& INT2 & 0.865 & \\
\hline
\end{tabular}

\subsection{Factor Analysis}

To find out how the indicator describes the construct or its latent variable, the factor load is used (factor loading). The factor loading threshold is greater than 0.5 or ideally greater than 0.7 [34]. The factor loading of the measurement model in this study is:

Table 6. Standardized factor loading

\begin{tabular}{lcc}
\hline Variable & Indicator & SFL \\
\hline Perceived Benefit & BEN1 & 0.84 \\
& BEN2 & 0.87 \\
& BEN3 & 0.76 \\
& BEN4 & $\mathbf{0 . 4 8}$ \\
Perceived Risk & RIS1 & 0.66 \\
& RIS2 & 0.75 \\
& RIS3 & 0.73 \\
Perceived Maqoshid Sharia & RIS4 & $\mathbf{0 . 5 2}$ \\
& SYR1 & $\mathbf{0 . 5 9}$ \\
& SYR2 & 0.67 \\
& SYR3 & 0.74 \\
& SYR4 & 0.81 \\
\hline
\end{tabular}

We apply 0.6 score of threshold Loading Factor. There are three indicators with Loading Factor score $<0.6$, those are BEN4 (.48), RIS4 (.52), and SYR1 (.59). We then exclude those three indicators due to not passing the threshold score. Finally, we have twelve indicators used to examine the impact of exogenous toward endogenous variable.

\subsection{Confirmatory Factor Analysis}

Confirmatory Factor Analysis (CFA) includes unidimensionality, construct validity, and construct reliability. Unidimensionality means that each indicator for one construct or variable is mutually associated with each other determined by a factor loading with a score limit between 0.5 and 0.7 . The construct validity is examined by testing convergent validity, which is the extent to which the indicators of the same construct are correlated. Convergent validity is tested by calculating Average Variance Extracted (AVE) $>0.5$. Construct reliability is tested using Composite / Construct Reliability (CR), which is an indicator of internal consistency of a construct [34-36]. As shown in following table, all latent variables are: 
Table 7. Standardized factor loading

\begin{tabular}{lccccc}
\hline Indicator & SFL & Error & SFL $^{2}$ & CR & AVE \\
\hline BEN1 & 0.86 & 0.26 & 0.74 & 0.868 & 0.687 \\
BEN2 & 0.88 & 0.23 & 0.77 & & \\
BEN3 & 0.74 & 0.45 & 0.55 & & \\
RIS1 & 0.67 & 0.55 & 0.45 & 0.757 & 0.510 \\
RIS2 & 0.75 & 0.44 & 0.56 & & \\
RIS3 & 0.72 & 0.48 & 0.52 & & \\
SYR2 & 0.69 & 0.52 & 0.48 & 0.773 & 0.514 \\
SYR3 & 0.72 & 0.48 & 0.52 & & \\
SYR4 & 0.82 & 0.45 & 0.55 & & \\
\hline
\end{tabular}

According to the table above, it could be seen that the model meets convergent validity and construct reliability with a value of $\mathrm{CR}>0.7$ and AVE $>0.5$ (Awang, 2012; Hair Jr et al., 2014; Wahyu Widhiarso, 2011). Based on these data it can be concluded that the research model is valid and reliable.

\subsection{Goodness of Fit Indices}

The model fit test is undertaken to see whether the proposed model is in accordance with the data. There are several indicators to evaluate the suitability of the model in representing data in accordance with the theory. There is no agreement on what indicators are the most dominant (Hooper, Coughlan, \& Mullen, 2008). Result of this test shows that Root mean square error of approximation (RMSEA) 0.043, Goodness-of-fit statistic (GFI) 0.97, Standardized root mean square residual (SRMR) 0.042, Normed-fit index (NFI) 0.98 and Comparative Fit Index (CFI) 0.99. From this five indicators of model fit we conclude that model was good enough and feasible to proceed to be analyzed.

\subsection{Structural Model}

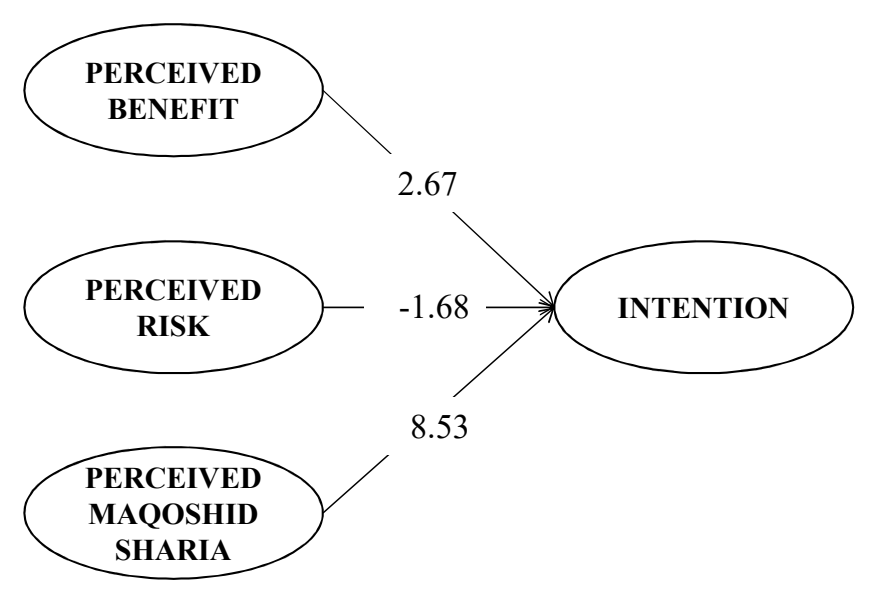

Figure 3. Structural model t-values

Figureure 3 shows the t-values of perceived benefit (2.67), perceived risk (-1.68), and perceived maqpshid sharia (8.53). from the data we summarized: perceived benefits has positive and significant impact (Hypotheses 1 acepted); perceived risk has negative and significant impact (Hypotheses 2 acepted); perceived maqashid sharia has positive and significant impact on intention to use Islamic fintech services (Hypotheses 3 acepted).

The structural equation of perceived benefit .14, perceived risk -.091, and perceived maqoshid sharia .51. All of variables simultaneously influence toward intention for $39 \%\left(\mathrm{R}^{2}=.39\right)$, while $61 \%$ determine by other factors. From this equation, we identified that perceived maqoshid sharia influence the investment intention the most compared to two other factors. 


\section{Conclusion}

The structural equation of perceived benefit .14, perceived risk - -.091 , and perceived maqoshid sharia .51 . All of variables simultaneously influence toward intention for $39 \%\left(\mathrm{R}^{2}=.39\right)$, while $61 \%$ determine by other factors. From this equation, we identified that perceived maqoshid sharia influence the investment intention the most compared to two other factors.

The intention to invest using Islamic Fintech is influenced by first, perceived maqoshid sharia. This is about how people perceive about how well Islamic Fintech implements the Islamic values on their business. Second, perceived risk gives negative impact to the intention, especially financial risk in particular. As we know that NDFI shall manage its credit risk that will lead to financial loss, Islamic shall also pay attention to this matter in order to provide security to the investor. Third, the benefit of Islamic Fintech has positive impact toward intention. This empirical summary shows that digital have made people life easier and more convenient. Islamic Fintech shall also pay attention to convenience factors.

This research is limited to see the perception of investor as Fintech customer. We recommend to undertake study from investee perception. Regarding to perceived maqoshid sharia, we recommend future research about how to measure people perception toward the implementation of Islamic values by Islamic Fintech or other Islamic financial institution.

\section{References}

[1] Lee I., Shin YJ.Lee I., Shin YJ., : Fintech: Ecosystem, business models, investment decisions, and challenges. Business Horizons. 'Kelley School of Business, Indiana University'; 2018; 61(1): 35-46.

[2] Schwab K.Schwab K., : The Fourth Industrial Revolution: what it means and how to respond. Foreign Affairs. 2015; (Desember): 2.

[3] Bank Indonesia.Bank Indonesia., : Buku Saku Keuangan Inklusif. 2014.

[4] Otoritas Jasa Keuangan.Otoritas Jasa Keuangan., : Perusahaan Fintech Lending Berizin dan Terdaftar di OJK Per Oktober 2018. 2018.

[5] Hadad MD.Hadad MD., : Financial technology (fintech) di Indonesia. Jakarta: Dipresentasikan dalam kuliah umum Indonesia Banking School (IBS).; (2017).

[6] Forsythe S., Liu C., Shannon D., Gardner LC.Forsythe S., Liu C., Shannon D., Gardner LC., : Development of a scale to measure the perceived benefits and risks of online shopping. Journal of Interactive Marketing. Journal of interactive Marketing. 2006; 20(2): 55-75.

[7] Tanadi T., Samadi B., Gharleghi B.Tanadi T., Samadi B., Gharleghi B., : The impact of perceived risks and perceived benefits to improve an online intention among generation- $Y$ in Malaysia. Asian Social Science. 2015 ; 11(26): 226-238

[8] Auda J.Auda J., : Maqasid Al Shari'Ah: an Introductory Guide. The International Institute of Islamic Thought. 2008;

[9] Chapra MU.Chapra MU., : The Islamic Vision of Development in the Light of Maqasid al-Shariah. The International Institute of Islamic Thought. 2008; (September): 57.

[10] Khamis MR.Khamis MR., : Measuring Religious Values Development Based on Maqasid Syariah Approach in Compliance Behavior of Business Zakat Scenario. Advances in Business Research International Journal. 2016;

[11] Mohamed M., Razak DA., Taib F.Mohamed M., Razak DA., Taib F., : The performance measures of Islamic banking based on the Maqasid Framework. IIUM International Accounting Conference (INTAC IV). 2008; 1967(June): 1-17.

[12] Khayruzzaman.Khayruzzaman., : Impact of Religiosity on Buying Behavior of Financial Products: A Literature Review. International Journal of Finance and Banking Research. 2016; 2(1): 18.

[13] Worthington EL., Wade NG., Hight TL., Ripley JS., McCullough ME., Berry JW., et al.Worthington EL., Wade NG., Hight TL., Ripley JS., McCullough ME., Berry JW., et al., : The Religious Commitment Inventory-10: Development, refinement, and validation of a brief scale for research and counseling. Journal of Counseling Psychology. 2003; 50(1): 84-96.

[14] Otoritas Jasa Keuangan.Otoritas Jasa Keuangan., : Salinan Peraturan Otoritas Jasa Keuangan Nomor 65/POJK.03/2016 tentang Penerapan Manajemen Risiko bagi Bank Umum Syariah dan Unit Usaha Syariah. 2016.

[15] Arner D., Barberis J., Buckley R.Arner D., Barberis J., Buckley R., : The evolution of fintech: a new post-crisis paradigm? University of New South Wales Law Research Series. Sydney; 2015.

[16] Price Waterhouse Coopers.Price Waterhouse Coopers., : Redrawing the lines: FinTech's growing influence on Financial Services. Global FinTech Report. 2017.

[17] Ajzen I.Ajzen I., : Consumer attitudes and behavior: the theory of planned behavior applied to food 
consumption decisions. Rivista di Economia Agraria. 2015; 70(February): 121-138. Available at:

[18] Vallerand RJ., Deshaies P., Cuerrier J-P., Pelletier LG.Vallerand RJ., Deshaies P., Cuerrier J-P., Pelletier LG., : Ajzen and Fishbein's theory of reasoned action as applied to moral behavior: A confirmatory analysis. Journal of Personality and Social Psychology. 1992; 62(1): 98-109.

[19] Kotler P., Keller KL., Brady M., Goodman M., Hansen T.Kotler P., Keller KL., Brady M., Goodman M., Hansen T., : Marketing Management, 15th Edition. Pearson Education Limited. (2016). 942 p.

[20] Medberg G.Medberg G., : Gustav MedberG-How do CustoMers PerCeive value-in-use? Helsinki: Hanken School of Economics; (2016). 174 p.

[21] Sinha I., DeSarbo WS.Sinha I., DeSarbo WS., : An Integrated Approach toward the Spatial Modeling of Perceived Customer Value. Journal of Marketing Research. 1998; 35(2): 236-239.

[22] Choi J., Lee A., Ok C.Choi J., Lee A., Ok C., : The Effects of Consumers' Perceived Risk and Benefit on Attitude and Behavioral Intention: A Study of Street Food. Journal of Travel and Tourism Marketing. 2013; 30(3): 222-237.

[23] Bettman JR.Bettman JR., : Perceived risk and its components: a model and empirical test. Journal of Marketing Research. 1986; 10(May 1973): 184-190.

[24] Association of Supervisors of Banks of the Americas.Association of Supervisors of Banks of the Americas., : An Overview of FinTechs: Their Benefits and Risks. Mexico City; 2017.

[25] Nora, Liza \& Minarti NS.Nora, Liza \& Minarti NS., : The role of religiosity, lifestyle, attitude as determinant purchase intention. The 2nd International Multidisciplinary Conference 2016. 2016; (October 2016): 135-148.

[26] Olufadi Y.Olufadi Y., : Muslim Daily Religiosity Assessment Scale (MUDRAS): A new instrument for Muslim religiosity research and practice. Psychology of Religion and Spirituality. 2017; 9(2): $165-179$.

[27] Zahrah MA.Zahrah MA., : Ushul Fiqh. Jakarta: Pustaka Firdaus; (2016).

[28] Atchariyachanvanich K., Sonehara N., Okada H.Atchariyachanvanich K., Sonehara N., Okada H., : What are the Benefits of Continued Purchasing through the Internet? A Study of South Korean Consumers. Journal of Service Science and Management. 2008; 1: 101-110.

[29] CFA Insitute.CFA Insitute., : Fintech Survey Report. CFA Institute. 2016. Available at: [30] Dusuki AW., Abdullah NI.Dusuki AW., Abdullah NI., : Why do Malaysian customers patronise Islamic banks? International Journal of Bank Marketing. 2007; 25(3): 142-160.

[31] Venkatesh., Morris., Davis.Venkatesh., Morris., Davis., : User Acceptance of Information Technology: Toward a Unified View. MIS Quarterly. 2003; 27(3): 425.

[32] Karaali D., Gumussoy CA., Calisir F.Karaali D., Gumussoy CA., Calisir F., : Factors affecting the intention to use a web-based learning system among blue-collar workers in the automotive industry. Computers in Human Behavior. Elsevier Ltd; 2011; 27(1): 343-354.

[33] Bejtkovský J.Bejtkovský J., : The Current Generations: The Baby Boomers, X, Y and Z in the Context of Human Capital Management of the 21st Century in Selected Corporations in the Czech Republic. Littera Scripta. 2016; 9(2): 25-45.

[34] Hair Jr JF., Black WC., Babin BJ., Anderson RE.Hair Jr JF., Black WC., Babin BJ., Anderson RE., : on Multivariate Data Analysis Joseph F . Hair Jr . William C . Black Seventh Edition. (2014). 11 p.

[35] Awang Z.Awang Z., : A Handbook on SEM. Kuala Lumpur: Centre For Graduate Studies, University Teknologi MARA Kelantan; (2012). 54-73 p.

[36] Wahyu Widhiarso.Wahyu Widhiarso., : Reliabilitas dan Validitas dalam Pemodelan Persamaan Struktural SEM 1 Pendahuluan 2 Reliabilitas Aitem. Universitas Gadjah Mada. 2011; : 1-13. 